\title{
"We Shall Overcome" A Humanity Song by Roger Waters: Critical Discourse Analysis
}

\author{
Inike Tesiana Putri; Sulis Triyono \\ Universitas Negeri Yogyakarta, Indonesia \\ Corresponding Author: iniketesianaputri@gmail.com
}

\begin{abstract}
Language is an essential feature of communication for all poeple. It is utilized through various tools and media, and singing songs is one of the traditional forms of communication. Songs are usually written for particular reasons, messages, and purposes, and sometimes targeted for specific audience or listeners. Song lyrics usually contain various themes such as social and current issues and problems which the songwriter strives to share through expressions of his or her ideology, thoughts and feelings. This paper is aimed to find out the text analysis, social cognition and social context in the humanity song entitled $W e$ Shall Overcome through Teun A. van Dijk's Critical Discourse Analysis model. This model shows that the choice of words or the diction is cohesive and coherent and is able to communicate the general meaning of this humanity song. Furthermore, the social cognition in this humanity song is related with the current social context which involves the recent situation in Palestinine, where there is still in conflict with Israel.
\end{abstract}

Keywords: lyric; humanity song; social context; critical discourse analysis; van Dijk

\section{INTRODUCTION}

Language is one of the most basic and fundamental parts of mankind as a means of communication, especially in societal interaction. It is an important tool in conveying or expressing feelings, ideas and thoughts.

Song is one of the medium of expression used to express one's thoughts or critical analysis about any particular subject. When a songwriter creates a song, he or she tends to have special meanings and thoughts attached to it, which he or she aims to be understood and accepted by the audience and listeners. Each songwriter has his or her own style based on the songwriter's language proficiency and background. A good songwriter will give strong attention to the language used, and it should be appreciated that in fact, it is not an easy feat at all to produce a good song. Creativity plays a pivotal role in determining the quality of songs. A lot of songwriters use figurative language in their works to give rise to the aesthetic function in the song lyrics. What makes a good songwriter is the one that manages to convey the feelings and invokes the intended emotions of the listeners' and audience', while having their songs rich in moral values.

The song lyric is a part of the discourse. Based on the amount of the speaker, narrator or writer, the song lyric includes monologue discourse, which is a part of the discourse analysis conveyed by one person. Tarigan (2009) conveyed that discourse is a linguistic text with a complete set of elements and bigger than the sentence or clause with the high intensity of cohesion or coherent. There are many types of discourse such as novels, books, articles, speeches, and song lyrics. The discourse analysis is not limited to linguistic studies. The discourse has a correlation with the context. The context appears in many elements, such as the narrator and listener (participant), setting of the place and time, situation, condition, message, end, key, instrument and norm (Hymes in Darma, 2009). Discourse is considered as 
the strongest purpose that will be reached. Sometimes, the discourse analysis represents the social problems and current issues. From these phenomena, it can be concluded that critical discourse analysis is a discourse which analyzes the use of language in discourse and the environment of language such as the social cognition and social context.

In this research, the researcher will conduct the discourse on a humanity song titled We Shall Overcome through Teun A. van Dijk's Critical Discourse Analysis model. This song is suitable for the situation and condition of the government of Palestine, which has been in conflict with Israel since 1948 until now. The researcher relies on the three problems which are manifested in the text analysis, the social cognition and the social context in the humanity song.

\section{The Humanity Song}

The humanity song underscores spiritual support spirit especially for a politically unstable country which suffers from conflict or colonialism. Humanity is a sympathetic attitude towards another person who has a problem or conflict. The conflict between Palestine and Israel has inspired many people to produce humanity songs to support the Palestinian victims who are afflicted by the Israeli aggression. The songs are famous throughout the world and are available as MP3 online for free. They have been downloaded by over half a million people from the official websites.

The humanity song titled We Shall Overcome is written for the Palestinians who have to battle and survive in the conflict with Israelis, especially with their army. Below is the song lyric for reference:

This is the song lyrics of the humanity song titled, We Shall Overcome by Roger Waters (Pink Floyd), length 4 minutes 48 seconds

We shall overcome

We shall overcome

We shall overcome some day

Deep in my heart

I do believe

That we shall overcome

Someday

And we'll walk hand in hand

We'll walk hand in hand

We'll walk hand in hand one day

Deep in my heart
I do believe

That we will walk hand in hand

One day

And we'll break down the prison walls

We will tear down those prison walls

Together we will tear down the prison walls on that day

Deep in my heart

I do believe

That we will tear down all those prison walls on that day

And the truth will set us free

The truth will set us free

The truth will set us all free

On that day

And, deep in my heart

I do believe

That the truth will set us all free

And we shall overcome

On that day

Source:https://marwaarafa.wordpress. com/2012/01/12/we-shall-overcome-by-pinkfloyds-roger-waters/

The song is actually an old song, used as an anthem song for protest. Not only that, this song is intended to be a call for justice. This song was first released in 1947 on People's songs bulletin. This song was adapted from a gospel song by Charles Albert Tindley, and it has been used in the soundtrack of a Hindustani movie My Name is Khan, which was produced by Karan Johar, and played by the lead actor Shah Rukh Khan. In the film, a black-skin boy sang the song in a church to inform the audience that they should not differentiate anyone based on their skin color. In the United Stated of America, though the politics of apartheid are dead, but discriminations and prejudices between people of black-skinned and white-skinned people are still prevalent.

However, on June $7^{\text {th }} 2010$, the singer Roger Waters from Pink Floyd released his version of the song sang recently to support the Palestinians who are in conflict with Israel by seeking to encourage them to stay strong against their aggressors, while encouraging global support for the Middle East Peace efforts. 


\section{The Current Issue of Palestine and Israel}

The conflict between Israel and Palestine has been going on for a long time. Perhaps due to the close proximity between the two countries, Israel has a strong desire and ambition to take over, dominate, control, manage and occupy the land of Palestine. Over the years, military tactics have involved various acts of war including bombing and torture, and the victims include children and babies.

Despite criticisms and protests from all over the world, the Israelite government continues to ravage the land of Palestine, including limiting and monitoring the freedom and movement of the Palestinian people without any care and sympathy towards their needs and the desires of the Palestinians. Their food supplies are always scarce, making starvation a usual theme. Unemployment is desperately low. The administrative activities are paralyzed, as is the economy and social growth. Luckily, the Palestinians are never poor in terms of sympathy from the world population who looks with disdain over what the Palestinians have to endure. They are provided with not just financial, but shelter, food, protection, and health care services. The support includes military strength as well.

But, the conflict has heated up again through the statements from the current President of the United State of America, Donald Trump who declared that Jerusalem is the capital of Israel and all of the embassies will begin to move there as soon as possible. The declaration is very controversial. The UN held a meeting to vote and decide about the way to move forward regarding the US and Israelite governments. The voting resulted in 128 countries disagreeing with Trump's statement since those countries recognize Jerusalem a part of the area in Palestine. Meanwhile, there are nine countries agreeing that Jerusalem is the capital of Israel and there are 35 countries who abstained from voting. The voting was held by the United Nations General Assembly in New York on December 21 $1^{\text {st }}, 2017$ (www.aljazeera.com).

\section{Discourse Analysis}

Among the experts who explain the definition of discourse are George Yule, Sara Mills, Roger Fowler, David Crystal, Geoffrey Leech and Michael Short, Geoffrey Hawthorn, Michel Foucault and Michael Stubbs. George Yule (2010) defined discourse as a language beyond the sentence and the analysis of discourse is concerned with the study of language texts and conversations. Tarigan (1987) stated that discourse is a linguistic unit with complete elements, higher than clause and sentence. It has the elements of good cohesion and coherence. A discourse can be seen in a written text or in a verbal form. Geoffrey Leech and Michael Short in Sara Mills (2004) argued that discourse is one of the linguistic communications which is seen as a transaction between the speaker and listener, writer and reader, and so forth. Crystal in Mills (2004) stated that discourse analysis focuses on the structure that naturally occurs in spoken language. It can be seen in daily conversation including speeches and interviews. Meanwhile, the discourse analysis in written text merely focuses on its structure. For instance, it can be seen in essays, articles, journals, novels and road signs.

Michael Stubbs in Mills (2004) differentiated between the use of discourse and text. Stubbs assumed that discourse is different from text, by noting that discourse is in verbal form while text is written, and a text is not interactive whereas a discourse is very interactive. The form of a text may be short and long whereas discourse is in a long form, and text is only on the surface cohesive while discourse needs more analysis and has deeper coherence. As such, it can be concluded that a discourse is a complete linguistic unit, higher than sentences which not only has cohesion but it has correlation among the elements and coherence.

Sumarlam (2009) classified the categories of discourse. There are two categories which relate to the characteristics of the user. The first category is a monologue discourse which is delivered by one person and is a one-way conversation in a communication and is not done interactively. This can be seen in speech, oration, novel, song, among others.

The second category of discourse is a dialogue discourse, or commonly known as a conversation. This category includes two ways of communicating, involving two persons and done interactively. It can be seen clearly in a forum or open discussion, seminar, conference, meeting, gathering, convention and many others.

\section{Critical Discourse Analysis}

Critical discourse analysis (CDA) is a type of research discourse analysis which primarily studies the abuse of social power, dominance, and the ways inequality are enacted, reproduced and resisted through texts and speeches in the social and political contexts. This critical discourse analysis examines explicit positions and seeks to understand, comprehend, recognize, and ultimately resist social inequality (van Dijk in Darma, 2009). Thus, it is not merely about the linguistic 
aspects, but also it has to correlate with the context of the discourse that occurred. Context means that the language is used in a particular purpose for a particular practice.

Fairclough and Wodak elaborated the most important principles of critical discourse analysis as follows; critical discourse analysis which focuses on social problems, power relations, the dilemma of society and culture, ideological works, historical, the relation between text and society which is mediated and interpretable, and the last is discourse is a figure of social action (Fairclough, 1997).

Fairclough and Wodak characterized critical discourse analysis as follows:

1. Action means that a discourse is an action. It is considered as something which has many purposes, for example to debate, influence, persuade, contrast, and act.

2. Critical discourse analysis refers to the setting of place, time, situation and condition. It can be understood, explained, interpreted and analyzed by the particular context. The context is related to the participant or the user, setting of place and time, situation, function, and et cetera.

3. Historical discourse relates to a certain historical context. In doing analysis, there needs to be a review of why the discourse develops over time, and why a certain language is used among others.

4. The power relations refers to the social view, which states that every discourse has power. The position of power in a discourse is very important because the function of power is to control someone or a group in social community. One person or group may control another person or group through a discourse.

5. Ideology can be explained by the purpose of ideology in a discourse is to manage, organize, arrange, persuade, direct and handle the problem which is occurring in a social community.

The discourse with this approach is considered to be a medium used by a dominant group to persuade or communicate with a minor group.

Van Dijk in Eriyanto (2011) emphasized that the research of discourse analysis is not only regarding analysis of the text but also the consideration on the result of production in a social practice. Van Dijk revealed that the dimensions of discourse consists of text, social cognition, and social context. The first dimension is a text which involves the text being used to examine the text structure and discourse strategy which is used to assert a particular theme. A text has three stages i.e. macrostructure, superstructure, and microstructure. The macrostructure is the general meaning of the text which can be seen or analyzed by the topic or theme. The superstructure is the part of the discourse structures which is related to the framework or scheme of the text and elements of the text which are arranged to be a good and complete text such as introduction, verse, bridge, chorus, refrain or reff, interlude, overtone and coda. The microstructure is the structure of the small part of the text such as words, sentences, propositions, coherences, and so on.

The second dimension is social cognition. A discourse does not only discuss and examine structure of the text but it also shows the meaning, ideology and purpose in the content of the text. It is intended to reveal the hidden meaning of the text, and a cognition analysis and analysis of the social context are required.

The third dimension is the social context. Discourse is a part of the discourses which arise in a social community. In analyzing a text, it must be correlated with intertextual analysis between how the discourse is produced and how the discourse is constructed in the society (Eriyanto, 2011). Furthermore, the social analysis has to correlate to the social problem, such as the power and the access or media to control, manage, organize, influence, and even to intimidate someone or the minor group circle:

Figure 1. Analysis Model of van Dijk

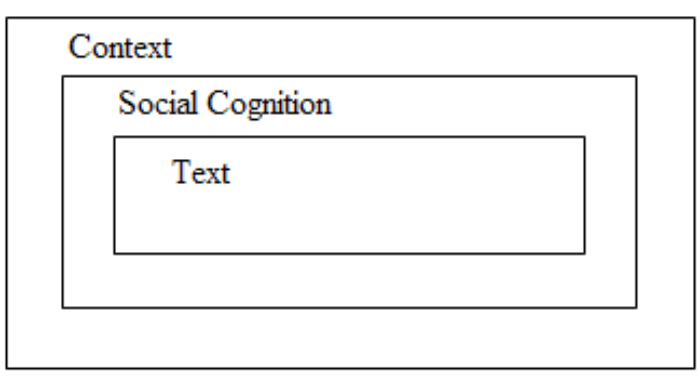

\section{Methods}

This research uses a methodological approach in the form of a descriptive qualitative study, which Sudaryanto (2015) asserted as an approach that will characterize the result of the study concerned with language by marking the use of the language step by step. Whereas, a qualitative approach relates to the 
data which is not in the form of numbers, but in words and pictures instead, using statements, sentences, quotations, descriptions or manuscript of interviews, photos, and videotapes (Moleong, 2007). This study addresses the following research objectives: to describe the text analysis, the social cognition and the social context in a humanity song titled We Shall Overcome by using the theory of Critical Discourse Analysis model from Teun A. van Dijk and examining the statements, sentences and descriptions. This research utilizes Padan and Agih methods. The former is used to examine or determine the identity of the determinant in a lingual unit from outside of the language while the latter is used to examine a lingual unit from inside of the language (Sudaryanto, 2015). Text analysis uses the Agih method while the social cognition and the social context uses the Padan method.

\section{FINDINGS AND DISCUSSION}

\section{Findings}

\section{Text Analysis}

There are three stages in the text analysis. They involve examining the macro structure, superstructure and macro structure. Macro structure is related to the general meaning or theme in the text. Superstructure has correlation with the structure of the discourse while the microstructure is related to the meaning of the discourse which is observed through the parts of the text.

\section{Macro Structure}

The subject matter being analyzed in the macro structure is the thematic elements that show the general meaning of the text. The general meaning is observed through the theme in the core ideas. The theme shows the crucial information or important goal in the text which is conveyed to the audience, readers or listeners. The theme can be obtained through reading the text as a whole. Each part of the text will lead to one element and those parts will support each other to illustrate a common theme.

This humanity song titled We Shall Overcome has a general theme about supporting and encouraging someone or a group of people to stay determined in achieving their goals and objectives. This song is intended to support Palestinians who are at war with the Israelites and fighting for their freedom. This song was used as a protest against the Israelite government.
This general theme is supported by several sub-themes which are interconnected and seen in the song lyric.

The lyric of humanity song for Palestine titled We Shall Overcome

We shall overcome

We shall overcome

We shall overcome some day

Deep in my heart

data

I do believe that we shall overcome someday

And we'll walk hand in hand

We'll walk hand in hand

We'll walk hand in hand one day

Deep in my heart

data

I do believe that we will walk hand in hand one day

And we'll break down the prison walls

We will tear down those prison walls

Together we will tear down the prison walls on that day

Deep in my heart

I do believe that we will tear down all those prison walls on that day

And the truth will set us free

The truth will set us free

The truth will set us all free on that day

And, deep in my heart

I do believe that the truth will set us all free on that day

And we shall overcome

On that day

\section{Superstructure}

Superstructure entails the construction of the text elements that have a good construction and have meaning. Generally, elements of the song lyric contain introduction, verse, bridge, chorus, interlude, modulation and coda.

\section{The song lyric of that humanity song}

We shall overcome title 
$\left.\begin{array}{l}\text { We shall overcome } \\ \text { We shall overcome } \\ \text { We shall overcome some day } \\ \text { Deep in my heart }\end{array}\right]$ verse

I do believe that we shall overcome
someday

And we'll walk hand in hand

We'll walk hand in hand

We'll walk hand in hand one day

verse

Deep in my heart

I do believe that we will walk hand in hand chorus one day

And we'll break down the prison walls

We will tear down those prison walls

Together we will tear down the prison walls on that day -----interlude------

Deep in my heart

I do believe that we will tear down all those prison walls

on that day

And the truth will set us free

The truth will set us free

The truth will set us all free on that day

And, deep in my heart

I do believe that the truth will set us all free on that day

And we shall overcome On that day verse

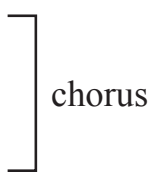
verse

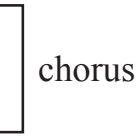

coda

Based on the result above, the elements of song lyric in humanity song contain the introduction, verse, chorus, interlude, and coda.

\section{Micro Structure}

The last main aims of the text analyzed in this structure included syntax, semantic and rhetoric. Generally, the microstructure is a structure of the small parts in the text such as the words, sentences, propositions, coherence and so on.

They are some syntax elements in this song lyric. First, there are active sentences such as We shall overcome, I do believe that we shall overcome someday, We'll walk hand in hand, I do believe that we will walk hand in hand one day, We'll break down the prison walls, We will tear down those prison walls, I do believe that we will tear down all those prison walls on that day, The truth will set us all free on that day, and I do believe that the truth will set us all free on that day. Second, there are some imperative sentences in this song lyric like We shall overcome. We'll break down the prison walls and We will tear down those prison walls. Third, there are some transitive verbs like I do believe that we shall overcome someday, We'll walk hand in hand, I do believe that we will walk hand in hand one day, We'll break down the prison walls, We will tear down those prison walls, I do believe that we will tear down all those prison walls on that day, and I do believe that the truth will set us all free on that day. Not only that, there is intransitive sentence i.e. We shall overcome. Fourth, this song has some repetitions such as: We shall overcome happens twice, We'll walk hand in hand happens twice, The truth will set us free happens twice, and The truth will set us free happens twice. Fifth, there are some personal pronouns like $W e, M y$, $I$, and $U s$.

The semantic element in this song is a songwriter who wants to convey the purpose by giving vocal support to the Palestinians. The rhetoric elements in this song lyric use metaphor which can be seen in the text, Deep in my heart, We'll walk hand in hand, And we'll break down the prison walls, We will tear down those prison walls, and The truth will set us free.

\section{Social Cognition}

The song titled We Shall Overcome by Roger Waters (Pink Floyd) was indeed created for the Palestinians as an action of resistance toward the Israel government and to unite the Palestinian people for their justice and freedom although this song is not originally for the Palestinians specifically.

\section{Social Context}

The third dimension of discourse analysis from van Dijk is the social analysis or social context in which the discourse is developed in the social community or society. From an intertextuality perspective, the discourse can be seen by examining how it is produced and constructed in the society. This famous song is known for its message which is always made as an anthem or theme for demonstrations and protests, mainly for causes such as peace and justice. 
Roger Waters then re-arranged this song to adapt it to the current situation and conditiond in Palestine. Moreover, the songwriter uses the word $W e$ in almost all of the lyric. The songwriter also uses the verb $d o$ before subject $I$ at every end of the stanzas. It can be seen in this lyric I do believe.

\section{Discussion \\ Text Analysis}

\section{Macro Structure}

There are four data to represent the macro structure in analyzing the text. Based on the findings above, there are the bold sentences which contain some sub-themes that support the main or general theme of the song lyric. Not only that, the compilation of sub-themes in the song lyric correlates with each other in constructing the general theme.

In the first data, the songwriter gives the support by saying the bold sentence We shall overcome some day and I do believe that we shall overcome someday. The songwriter believes that all the problems faced by the Palestinians will be over soon. This songwriter is convinced we (the Palestinians) will overcome the problems and all the problems will be solved well.

In the second data, the songwriter wants to walk and feel the freedom together, while also enjoying the moment of freedom because the war had ended. In addition, the songwriter wanted to emphasize that Palestinians are not alone as they have global support. It can be proved by these lyrics We'll walk hand in hand one day and I do believe that we will walk hand in hand one day. Those lyrics contain the metaphorical meaning or implicit meaning. The word we refers to many entities or a plurality of people. It means that we can work as many countries to give supports and encourage the Palestine government. All the problems can be solved easily with the help and support from many countries.

The third data is where the songwriter explains the prison walls in the lyric which also contains metaphorical and implicit meaning too: And we'll break down the prison walls and We will tear down those prison walls. It means that they (the Palestinians) feel like prisoners, imprisoned by the Israelis in their own country.

The last data is where the songwriter wants to give support to the Palestinians who dream, crave and want an absolute truth and justice. These are the song lyrics which are related to this text: The truth will set us all free on that day and I do believe that the truth will set us all free on that day.

\section{Superstructure}

This song was built on five elements; introduction, verse, chorus, interlude, and coda. The songwriter used the traditional title, We Shall Overcome to represent all of the contents in the song lyric. This song begins with a musical instrument, which is the introduction before going into the stanzas of the song.

Every stanza consists of verse and chorus. The songwriter only highlights the significance of the song without preamble. The verse is a part of introduction in the song before going into the next section, the chorus. The chorus is the main part or core of the message in the song, which is to give support to the Palestinians to face the war and conflict with the Israel government. This song also contains an interlude, which is the blank space of the song. Interlude has the same function with the introduction but the position of the interlude is in the middle of the song. Interlude connects with the next track section of the song, i.e. chorus, verse, and the last is coda, which contains the final tones and stanza to close the song. Another function of the coda is to emphasize the content of the song lyric. The songwriter wants to show and emphasize the embodiment of sympathy and support to the victims (the Palestinians). The songwriter strongly believes that the Palestinians can survive, face and overcome the problem.

\section{Micro Structure}

Based on the result above, the micro structure consists of the syntax, semantic, and rhetoric elements. The syntax element is the arrangement of the collected words or phrases to create the well-formed sentences in the language. The semantic element is related to the meaning in the language. The rhetoric element is related of how and by means of emphasis are made in written or oral form.

Syntax elements can be seen in the active sentences in the lyric, which occurs when the subject of the sentence as an actor in the sentence and the location of the subject is in front of the sentence. All of the active sentences have same characteristics, they are the subject in front of the sentence. After subject, it is followed by to be, verb, object, and adverb. Secondly, this humanity song contains some imperative sentences. Imperative sentence is a type of sentence used to create request, command, and direction. Sometimes, an imperative sentence is not necessary to have a subject because it is considered to be impliedly understood. The imperative sentence of the song lyric uses a subject $W e$ that persuades and 
demands support for the Palestinians. Third, there are some transitive and intransitive verbs in the lyric. A transitive verb is a verb which requires an object to complete the meaning while, an intransitive does not need any object. Fourth, there are some repetitions in this song, which are the four stanzas. Based on the results above, the repetition in every stanza occurs twice. Fifth, there are some personal pronouns such as $W e$ as personal subject pronoun (plural), $I$ as personal subject pronoun (singular), Us as personal object pronoun (plural) and $M y$ as possessive determiner (singular).

The semantic elements in this song involve the songwriter expressing and revealing the purpose by supporting the Palestinians who are in war and conflict with Israelites government. The songwriter wants to convince the Palestinians to stay strong. It can be seen in these lyrics We shall overcome and $I$ do believe.

The rhetoric elements in this song lyric use metaphor. In a discourse, a writer or songwriter not only conveys a fundamental message in the text, but also uses figurative language or figures of speech like metaphor, which is a figure of speech which compares one thing to another without the conjunction words like and as.

\section{Social Cognition}

This song is meant to support the Palestinians who are currently at war against the Israel government, while also calling for global support. The Palestinians desire for justice and freedom. This song was used as a protest against the Israel government and as a moral support for Palestinians.

\section{Social Context}

What is unique about the song is the correlation with the current situation and the harsh political conditions of the Palestinians. The Palestinians continue to have conflict with the Israeli government who seeks to make Palestine a part of Israel, resulting in mass killing and savagery through various acts of war such as bombing.

The songwriter chose the word We throughout the lyric to show togetherness in supporting the Palestinians. The songwriter also uses the word $d o$ before the subject $I$ at the end of every stanza. The function of $d o$ in this song lyric includes the positive framing of the sentence. It is used for emphasis. It is not for adding to the meaning in the sentence, but it makes the sentence which contains subject $+d o$ become much stronger. The songwriter strongly believes that the Palestinians will be free from the Israelite government.

\section{CONCLUSION}

This paper utilizes van Dijk's critical discourse analysis theory which consists of text analysis, social cognition, and social context. The text analysis examines three stages in the text analysis; macro structure, superstructure and micro structure. The macro structure is related to the general meaning or theme in the text. The superstructure has correlation with the structure of the discourse while the microstructure is related to the meaning of the discourse which is observed throughout the text. In the social cognition analysis, discourse does not only discuss and examine the structure of the text, but also shows the meaning, ideology and purpose in the content of the text. It is intended to reveal the hidden meaning of the text, while requiring cognition and social context analysis. The third dimension is the social context. Discourse is a part of the discourse which arises in a social community. In analyzing a text, it must be correlated with intertextual analysis between how the discourse is produced and how the discourse is constructed in the society and it has been proven that the social analysis is correlated to the present day Palestinian conflict and their social problems (Eriyanto, 2011).

\section{REFERENCES}

Darma, Yoce Aliah (2009). Analisis Wacana Kritis. Bandung: Yrama Widya.

Eriyanto (2011). Analisis Wacana Pengantar Analisis Teks Media. Yogyakarta: PT LkiS Printing Cemerlang.

Fairclough, N.L. and Wodak, R. (1997). Critical discourse analysis in T. A. van Dijk (ed.), Discourse Srudies. A Multidisciplinary Introduction, Vol. 2. Discourse as Social Interaction (pp.258-84). London: Sage.

Mills, Sara (2004). Discourse. London: Routledge.

Moleong (2007). Metodologi Penelitian Kualitatif. Edisi Revisi. Jawa Barat: PT. Remaja Rosdakarya.

Sudaryanto (2015). Metode dan Aneka Teknik Analisis Bahasa: Pengantar Penelitian Wahana Kebudayaan Secara Linguistik. Yogyakarta: Sanata Dharma University Press.

Sumarlam, dkk. (2009). Analisis Wacana. Solo: Pustaka Cakra Surakarta. 
Tarigan, Henry Guntur (1987). Pengajaran Wacana. Bandung: Angkasa.

Tarigan, Henry Guntur (2009). Pengajaran Wacana. Bandung: PT. Angkasa.

Yule, George (2010). The Study of Language. New York: Cambridge University.

\section{Internet Source:}

www.aljazeera.com accessed on December ${ }^{27}, 201721: 41$ https://marwaarafa.wordpress.com/2012/01/12/weshall-overcome-by-pink-floyds-roger-waters/ accessed on December ${ }^{23}, 2017$ 09:27. 